\title{
Epiphany
}

Epiphany: Vol. 6, No. 2, 2013

ISSN 1840-3719

\section{Winstanley's Utopia in Literature and in Cinema}

Alice Manuela Martins Guimaraes*

\begin{abstract}
Trying to achieve a perfect or better society for living, men dared, from the very beginning of his existence, to fulfill their own utopias. This was the case of Winstanley, a man who during the Interregnum envisioned for the future of the English Commonwealth the establishment of a rural communism as he believed "the earth was a common treasure for all." Beginning his utopia with an impulse to act and a call for action: "If you don't act, you do nothing" Winstanley, failed setting up the Diggers communities with whom he established proto-socialist communes. However he still continued to act, but this time "digging in the pages" and not in ground as he had done with the Diggers. Based in his previous experience with Diggers communities he wrote then his remarkable utopia, The Law of Freedom, which he dedicated to Oliver Cromwell, urging the English people to emulate it. Once more he wasn't succeeded with his words and only in the twentieth century historians and film makers found in his pamphlets and his literary utopia, a remarkable literary and historic resource to depict the socio-political reality of the Interregnum period. So it would be in cinema through the shot of image, that Winstanley's utopia would be relived and restored it to life. Through this remarkable intersemiotic transpose we realize that the process of writing can be regarded as the process of picturing as both try to piece together or, in other words, "remember" fragments of recollections from the past, of haunting guilt and traumas, beautiful dreams and aspirations, or visions of utopias that far from being fixed entities, are, rather, an endless and unfinished process filled with clashes and conflicts.
\end{abstract}

Keywords: Winstanley, Utopia, Literature and Cinema

*Corresponding author: Alice Manuela Martins Guimaraes; Assistant Professor The Humanities Department,Open University, Portugal; e-mail: aligui2@hotmail.com 
Utopia can be understood as a project for a future society in which man achieves a better and happy way of life. The ability to imagine, dream and speculate about the future, seems to be a defining characteristic of humanity. The creation of perfect worlds of paradises, a remote past, or a better future can be found in different civilizations throughout history. This dream of a fair society seems to haunt the human imagination at all ages, no matter whether it is called the Kingdom of Heaven, or the classless society, or if it is considered as a Golden Age, a time that existed in the past and which we can have degenerated (Orwell appud Kumar, 1987:2).

Actually, the place of ideal society (utopia) and the place of happiness (eutopia) are represented in the literary traditions either as a nostalgic mode of paradise lost, or on the form of the hopping millennium to come. According to Frank and Fritzie Emanuel "the utopia is a hybrid plant born of the interweaving of Judeo-Christian belief in a different world and paradise, with the Greek myth of an ideal city on Earth" (1997:15). This hybrid dates back to the origins of European civilization and the heterogeneity of Hellenic origin philosophies and religious-spiritual doctrines, of Jewish origin.

In the face of this duality, between the nostalgia for a lost past and the anticipation of a hopeful reality, utopia is defined for some, as a distant reality projection of the existing policy at the exact time of the literary text writing, a proactive intelligence related to historical events which will be achieved at a later date, a desire for renewal that collides with the ordinary mentality. However, for others, it is a historical current of social renewal, founded on values and needs that are considered essential - such as freedom, equality, justice, brotherhood - which have been forgotten or neglected, being therefore the continuous return of these values and needs.

But if the utopia thinking dates back to the beginnings of human existence, the utopia as literary genre, will only be coined by Thomas More in the 16th century. Its long Latin title Libellus vere aureus, nec 
minus salutaris quam festivus, de optimo rei publicae statu deque nova insula Utopia ("A truly golden handbook, no less beneficial than entertaining concerning the highest state of the republic and the new island Utopia"; 1516) included the defining neologism, which no lexicon had until then registered, of a fictional place homologous with an ideal society. The definitions that have sprung out of this new literary form are not, however, consensual regarding its thematic scope and formal structure, and even less concerning its genealogy. Despite all the differences of criteria, it seems that anthologists and experts of literary Utopia are all in agreement in considering fictional texts and politicodoctrinal conceptions whose aims are either the optimum or the worst representation of the organization of a human social community as all belonging to the same category. The neologism Utopia invented by Thomas More works, therefore, at both a literary-genre level and at a theoretical-doctrinal level (J. E. Reis).

As there is no consensus concerning the ambiguous concept I will follow, in this paper, the definition advanced by Ruth Levitas in her work, The Concept of Utopia, where she takes almost whole book to discuss the reasons this definition surpasses others, whether those formulated descriptively, formally, or functionally. Utopia expresses and explores what is desired; under certain conditions it also contains the hope that these desires may be met in reality, rather than merely in fantasy. The essential element in utopia is not hope, but desire - the desire for a better way of living (Levitas, 1990: 191). Her definition is particularly helpful for me, in looking at what strikes me as clearly utopian discourse in Winstanley's literary speech and in the eponym film where this visionary man envisioned for the future of the English commonwealth the establishment of a rural communism as he believed that "earth was a common treasure for all".

Gerrard Winstanley, the leader of the Digger's movement outlined in detail an egalitarian utopia in which a Parliament elected by universal suffrage decided the law, and the law was enforced by unpaid officers of the state. Everyone had to work and egalitarianism was strictly enforced. 
With the publication of his tract: The New Law of Righteousness (1649), Winstanley outlined his vision of a different social order. "Action is the life of all," he proclaimed in his Digger writings, "and if thou dost not act, thou dost nothing" (1649: 315), for he acutely perceived that in this period of turmoil "every one talks of freedome, but there are but few that act for freedome" (1649:317). In his career as communist, visionary, writer and Digger, prophetic words and symbolic actions would interact since "words and action going together are the declaration of a sincere heart" (1649:138). Commanded by the voice of the Spirit within, he would declare his message of visionary revelation, his new law of righteousness as he called it, both "by [his] pen" and "in [his] action" (1649:194).

Nowadays we can definitely say that Gerard Winstanley played a crucial role in a popular revolt in the middle decades of the seventeenth century that saw seven years of civil war - a period of the greatest social, political, and religious upheaval in the course of English history. He was an original and passionate thinker and visionary, who asserted that the real split in English life lay between those who worked the land and those who owned it. According to him, the common people should have equal rights to ownership with the gentry and the clergy. In April 1649, not long after the execution of Charles I by the Parliamentarians, he had led a band of about forty people, impoverished and dispossessed, onto common land on St George's Hill in Surrey. There they cultivated crops and established a community of 'Diggers'. Winstanley had expected to witness the restitution of the land to the English people. Seeing no evidence for that yet, he trusted that his own community of 'Diggers' would show the way. But that wasn't actually its end.

Despite their visionary utopianism, the Diggers, found themselves rejected by the larger culture as they encountered intense hostility and mob violence: they were physically assaulted, arrested, and imprisoned; their crops were spoiled, their farm tools destroyed, and their houses pulled down or burned. The Diggers' experience - although dispersed in 1649 by neighboring landlords and the soldiers of General Fairfax - was 
Winstanley's first step in the reclamation by common people of English lands.

In his literary utopia The Law of Freedom in a Platform (1652), he supported his rhetorical speech in two sources - his own experience with Diggers' community and the Bible. In the latter he turned to ancient Israel for his model. His commonwealth focuses on social equality, with a specific emphasis on the lower classes and on a political and social application of his form of Puritanism. Furthermore, he based his arguments on the religious doctrine that common possession is more commendable and more Christian than private property and also upon an appeal to the code of nature. He defended that private property in land was contrary both to the laws of nature and the will of God. $\mathrm{He}$ envisioned the constitution of a communistic society in which all land was held in common, all buying and selling was abolished, all citizens were educated by the state, and all people were eligible for the rotating offices of magistracy. Democratic government, economic equality and genuine freedom are outgrowths and manifestations of the inherent human desire for the survival of the species and the attainment of a good society. Thus, we definitely see his collectivist theories and practices strikingly anticipating the nineteenth - and twentieth-century socialism.

Nevertheless he was a voice crying in the wilderness of prevailing covetousness and tyranny; a voice which was forcefully muted. The spirit of covetousness could be overcome by the spirit of Christ. "There shall be no buying nor selling, no fairs nor market, but the whole earth shall be a common treasury for every man, for the earth is the Lord's". His perception that political, spiritual, and individual freedom must begin with economic freedom and common ownership of the land has received valuable attention from historians studying the Digger movement in relation to his radical sociopolitical environment. However, often more concerned with social, political, or religious ideas, such historical works rarely considers in any detail the rich figurative, and verbal dimensions of Winstanley's texts. Scholarly interest in Winstanley in general is relatively recent. 
His story was virtually forgotten until the late nineteenth century. It was only in the 1890s that Winstanley's works were dug up again. Later, in the 1940s, a complete edition of Winstanley's writings, edited by George Sabine, was published for the first time. In 1984 G. E. Aylmer observes the Winstanley had been largely forgotten for two centuries, and that even after his work attracted the attention of late nineteenth century historians, he remained obscure until the 1960s. Not until the resurrection by Bernstein (1985) was attention first directed to the fact that the most advanced thinker of the English Revolution had been completely neglected by its historians. And only recently, (in the 1960s and 1970s), have historians, novelists, and filmmakers such as Christopher Hill, David Caute, and Kevin Brownlow, respectively, portrayed him as a radical, Christian communist fighting for the rights of the underdog.

It's my purpose in this paper to redeem Winstanley's utopia which has been ignored and silenced by his contemporary critics. In fact, we can consider he was far in advance his epoch. His utopia can be understood as proto-communism since the combination of his unorthodox political beliefs and his radical political agenda have marked him as a progressive thinker whose ideas presaged those of later communist revolutionaries. As Lewis H. Berens puts it: "He was, in truth, one of the most courageous, far-seeing and philosophic preachers of social righteousness that England has given to the world" (171).

If only too late did Winstanley's utopia display in literature a remarkable blueprint, it would be only in the twentieth century that the film paid homage to it. Being the relevance of his pamphlets and his literary utopia, a remarkable literary and historic resource to depict the socio-political reality of the Interregnum, the cinema, on the other hand, through the shot of image, would revisit his utopia, in a wonderful voyage to the seventeenth century England, through which we learn about the leftist avant-garde. Actually, the film tells us a lot about the aesthetics of the radical left, on a period in which, as Christopher Hill put it: "the world was turned upside down". During this period, the search for perfection 
was part of the apocalyptic design that dominates the Puritan revolutionaries in England and, by extension, Winstanley himself.

The film, a travel back to the seventeenth century, to the political ambitions of the Interregnum society and to Winstanley's utopia, used a mix of close-up detail and near-fanatical authenticity, with much dialogue drawn from this period writings. It is also a truly amazing account of misery, as it depicts those whose cause is righteous and nonviolent". Directed by Kevin Brownlow and Andre Mollo (1975) the script was based on David Caute's novel, Comrade Jacob (1961), and had drawn explicit parallels between events of 1651 on St George's Hill and the present day. It evokes the civil war mood of the mid 1600s - where Cromwell's parliamentary forces defeated and beheaded the king. While retaining key scenes and some dialogue from Caute's novel, the script turned to additional sources, notably to the historical facts presented by historian Christopher Hill and to Winstanley's own writings which survive in the British Museum and constitute a real diary of the Diggers community spent at St. George's Hill (the same pamphlets which Marx read in the British Museum while forming his ideas on communism). So this film is a hybrid of Caute's novel and the genuine contemporary events described in the literary work of Gerrard Winstanley.

Retained from the Caute's novel are incidents such as the execution of a mutineer by Cromwell's soldiers after the suppression of the Ware mutiny; Fairfax's inspection of the Diggers commune; Fairfax's dialogue with Winstanley and William Everard (the remarkable interview in which Winstanley refused to take his hat) and Winstanley's plea to Tom Haydon to observe nonviolence rather than food theft by force as was happening in the village. From Winstanley's literary utopia are drawn historical elements, his utopian vision and his own words which were frequently reproduced in voice over to set scenes and context. The film reminds us that Winstanley is one of the most challenging of English visionaries and (as it includes generous quotations from his pamphlets) one of the finest of English writers. 
The film opens with a prologue in which Prokofiev's Alexander Nevsky score accompanies a battle scene, punctuated by explanatory intertitles ("1646: The King Against Parliament" reads the first). In his script foregrounds Winstanley's personal, day-to-day struggles in keeping his Diggers together, his fight with the Authorities for individual rights, and, in the end, his disillusionment and defeat. Its authenticity is overwhelming. The sense of time and place, visible in every costume and location, in the rust, the mud and decay, or on the faces of the unprofessional cast who spoke the words with an untrained innocence that makes us believe every second of their interactions, their politics and ideals, is alive in every frame. There are no 'stars' here, just faces. Honest faces, plain faces, ugly faces looking at the shadows on the hillside, with a wet-eyed optimism that is touching in its integrity. The extraordinary beauty of the landscapes-especially images of the farmers silhouetted against the windblown skies and meadows.

The movie challenged us to become as fascinated and obsessed with the mysteries of the past as the filmmakers were. They even went so far as to scour England and consult animal-husbandry experts to find birds, cows, and pigs that were most likely to resemble those of the 17th century and to transfer a barn from Essex. Here, there was no sense that history had already happened rather, it seemed to be happening then and lies open to the view and analysis of hindsight. Instead of the final image of a humiliated Winstanley, as in Caute's novel, we are left in the film with only the gentle echo of his words from one of his latest pamphlets on the soundtrack as falling snow softly covers the bleak landscape. And it was with those words that the film concluded:

Here I end, having put my arm as far as my strength will go, to advance righteousness. I have writ, I have acted, I have peace. Now I must wait to see the spirit do its own work in the hearts of others . . . [and learn if] England shall be the first land or some other wherein Truth shall sit down in triumph. (A Bill of Account of the most Remarkable Sufferings that the Diggers Have Met with from the Great red Dragons Power since April 1, 1649) 
Anyway, as we have seen through his literary discourse, Winstanley was always aware that his actions would turn against him people of great influence and power. So he wrote: "Freedom is the man that will turn the world upside down, therefore no wonder he hath enemies" (Winstanley, 1983: 128). Far from expressing a naive desire for the restoration of a long-lost paradise, Winstanley's recasting of the past provides the basis for a challenging consideration of issues such as natural rights and the law, but also, quite importantly, a fascinating critique of violence that is intricately interconnected with the philosophy and praxis of the digging experiments launched in Surrey from 1649 to 1650.

Even if one doesn't enjoy black-and-white movies every moment that we're watching in this film, won't be forgotten. They seep into our consciousness like the photos in the most intimate of family albums, redefining who we are in that process. To understand who we are, we need to establish a certain distance from those who came before us; however, we also need to establish certain continuity. The dialectics between continuity and discontinuity in relation to our past must always be renegotiated.

The breaking of all canons, the juxtaposition of macro and micro history, the questioning of the ideas of objectivity and subjectivity in the historiographical rendering, as well as in literature, have taught us all to be prudent observers and to use the plural instead of the singular: no longer a unique "utopia," but many "utopias," many traces left by the same event which in time sediment in the individual consciousness, as well as in the collective consciousness, and that are often hidden or removed; suddenly re-emerging each time in the historical, political, or cultural context changes. The accent placed on the possibility of "reconstructing" and representing trauma has foregrounded sources such as diaries, autobiographies, pamphlets, testimonies, narrations (fictions), films, not only as individual expressions, but also as cultural structures exposing narratives of imagination and opposition. There is a dynamic and perhaps positive aspect which links past utopias and political issues 
which today underpin the molding of a European scenario, as they can help to sort out new strategies for assessing controversial memories of the same past.

\section{References}

Berens Lewis H. 2007. The Digger Movement in the Days of the Commonwealth. Wales: Merlin Press.

Bloch, E. 1976. Le Principe d'Espérance. Trad. Françoise Wuilmart. Paris: Gallimard.

Caute, David. 1961. Comrade Jacob. New York: Pantheon.

Eliav-Feldom, Miriam. 1982. Realistic Utopias: The Ideal Imaginary Societies of the Renaissance, 1516-1630. Oxford: Clarendon.

Kumar, Krishan. 1987. Utopia and Anti-Utopia in Modern Times. Oxford and New York: Blackwell.

Levitas, Ruth. 1990. The Concept of Utopia. Syracuse: Syracuse UP.

Lewycka, Marina author. 2009. New Statesman. Volume: 138. Issue: 4959.

Manuel, Frank / Fritzie, Manuel. 1997. Utopian Thought in the Western World, Cambridge, Massachussetts, The Belknap Press of Harvard University Press.

More, Sir Thomas. 1989. Utopia, Ed. George M. Logan and Robert M. Adams. Cambridge: Cambridge University Press.

Reis, José Eduardo. No year. The Gender of Utopia and the mode of Utopianism. Porto: FLUP

Richardson, Robert. 1969. Literature and Film, Bloomington-London: Indiana University press.

Winstanley, Gerrard. 1983. The Law of Freedom and Other Writings, Ed. Christopher Hill, Cambridge: Cambridge University Press. . 1649. The New Law of Righteousness in The Works of

Gerrard Winstanley, Ed. George H. Sabine, New York: Russel and Russel.

Winstanley. 1975. Film, Dir. Kevin Brownlow and Andrew Mollo, Milestone Collection. E.U.A.: British Film Institute Producers. 